\title{
Uncertainty in collaborative NPD: Effects on the selection of technology and supplier
}

\author{
Lisa Melander and Fredrik Tell
}

\section{Linköping University Post Print}

\section{Tweet}

N.B.: When citing this work, cite the original article.

Original Publication:

Lisa Melander and Fredrik Tell, Uncertainty in collaborative NPD: Effects on the selection of technology and supplier, 2014, Journal of engineering and technology management, (31), 1, 103-119.

http://dx.doi.org/10.1016/j.jengtecman.2013.10.009

Copyright: Elsevier http://www.elsevier.com/

Postprint available at: Linköping University Electronic Press

http://urn.kb.se/resolve?urn=urn:nbn:se:liu:diva-102343 


\title{
Uncertainty in collaborative NPD: effects on the selection of technology and supplier
}

\author{
Lisa Melander \\ lisa.melander@liu.se \\ Linköping University \\ Department of Management and Engineering \\ SE-58183 Linköping
}

Sweden

Fredrik Tell*

fredrik.tell@liu.se

Linköping University

KITE Research Group

Department of Management and Engineering

SE-58183 Linköping

Sweden

*Corresponding author, telephone: +46 (0)13 282599 


\section{Uncertainty in collaborative NPD: effects on the}

selection of technology and supplier 


\begin{abstract}
To gain competitive advantage, firms involve suppliers in New Product Development (NPD). However, uncertainty affects selection of suppliers and associated technologies, and selection outcomes in terms of commitment to one supplier or maintaining flexibility. We report on a case study of collaborative NPD with the aim to develop an energy storage unit. The case involved selection of both technology and supplier, where both were changed during the NPD. Drawing upon Hall et al. (2011), we analyze technological, organizational and commercial uncertainties. We demonstrate how technological, commercial and organizational uncertainties cause firms to seek flexibility rather than commitment to one supplier.
\end{abstract}

Keywords: Collaborative R\&D, Technology selection, Supplier involvement, Power Systems, R\&D Management, Energy storage

Classification codes: L14, L24, O31, O32 


\section{Introduction}

As many firms choose to specialize in order to gain competitive advantages, they increasingly rely on other firms for the knowledge they need to develop, manufacture and market their products. Such complementary and specialized knowledge needs to be integrated with the knowledge of the focal firm (Grant and Baden Fuller, 2004; Johansson et al., 2011; Teece, 1986). One case in point is the increasing importance of the involvement of suppliers in New Product Development (NPD) projects. Firms strive to involve suppliers in their development projects and require that suppliers contribute their knowledge to the development process in order for the firm to get access to, and exploit, new technology. Extant literature has pointed to the advantages of involving suppliers in the development process (Bonaccorsi and Lipparini, 1994; Clark, 1989; Handfield et al., 1999; Petersen et al., 2003; Ragatz et al., 2002; Ragatz et al., 1997; Song and Di Benedetto, 2008; Walter, 2003) and highlights reductions in cost and time, improvement in quality and performance as some of the advantages of this involvement. In addition, having a close relationship with key suppliers has proved to be an effective way for firms to draw upon, and benefit from the capabilities of technologically advanced suppliers in developing new products (Kamath and Liker, 1994).

Studies also show mixed results on projects' speed when involving suppliers in product development (Eisenhardt and Tabrizi, 1995), where supplier involvement in predictable projects showed positive effects while no effect was shown in more uncertain projects. One explanation may be that the success of supplier involvement is contingent upon the process of evaluating and selecting the supplier for collaboration (Petersen et al., 2003). For instance, selecting a suitable supplier involves finding one with complementary knowledge, and that at the same time is easy to collaborate with, is committed and keeps promises. A challenging feature of supplier selection in NPD contexts in comparison to, for instance, manufacturing, is that the rate and direction of technological change arguably is an even more important factor. Oftentimes there are different technological designs and architectures evolving concomitantly, where suppliers may probe diverse technological trajectories. The selection of suppliers for NPD collaboration thus involves uncertainties pertaining both to the supplier as well as the technological frontier. Accordingly, we pose the following research questions: how do different types of uncertainty affect technology selection and supplier selection, respectively? How do such uncertainties influence selection outcomes, in terms of flexibility or commitment to suppliers? There is a shortage of studies focusing on how suppliers are 
selected for collaboration in NPD projects. In particular, previous research has not focused on different types of uncertainty in the selection phase of collaborative NPD and how such uncertainties influence the selection process and its outcomes. Therefore, the purpose of the study reported here is to analyse uncertainties in technology selection and supplier selection in collaborative NPD, more specifically aiming a) to present a classification of different types of uncertainty, and b) to discuss how these different types of uncertainties affect supplier selection.

In this paper, we describe and analyse the selection of both the technology and the supplier in a complex and novel NPD project in the energy sector. We present an empirical study of a collaborative NPD project that was conducted to develop an energy storage unit for integration in advanced power grid applications. In this project, the buyer faced uncertainties both when selecting the technology and the supplier. First, the buyer selected one technology and one supplier in order to establish a joint development. This collaboration was discontinued and another technology and supplier was selected, with the buying firm seeking more flexible terms. Using a classification of uncertainties developed by Hall et al. (2011), our analysis suggests that buying firms may need to seek flexibility in supplier selection in situations where technological, organizational and commercial uncertainty prevail. We discuss specific problems associated with each type of uncertainty. Technological uncertainty primarily revolves around techno-paradigmatic and complexity-related problems, in which discontinuous change and high complexity may call for flexibility. Organizational uncertainty primarily concerns problems of inter- and intra-organizational fit, where low fit may necessitate openness to flexibility rather than strong commitment to one supplier. Commercial uncertainty involves problems regarding cost, supplier appropriation, supplier migration in the value chain, and leakage conditions. Flexibility decisions may be based on: non-predictable cost developments, non-proprietary technology, a high threat of supplier migration in the value chain, and a high risk of leakage from suppliers to competitors.

The paper is structured as follows. Section 2 reviews some of the literature on innovation, uncertainty and supplier selection. In section 3 we describe the research methodology and design of the empirical case study. Section 4 presents the case study of supplier selection in the development of a new battery storage unit for electrical power transmission systems. In section 5, we analyse the case with regard to technological, organizational and commercial uncertainty. Section 6 provides conclusions and implications for management and research. 


\section{Innovation, uncertainty, and supplier selection}

\section{Innovation and uncertainty}

Innovation involves the activity of bringing the invention of something (e.g. a product, a manufacturing process, raw materials, or an organization) to the market, or the opening up of a new market (Schumpeter, 1947: 66). In line with a great deal of innovation literature, we focus on product innovations (see Fagerberg, 2004). Although product innovations essentially consist of new combinations of knowledge rather than entirely new knowledge, invention and innovation involve uncertainty, both regarding the inputs (e.g. available knowledge and technologies) as well as outputs (e.g. demand characteristics and opportunities for acceptance and diffusion of the innovation). The study reported in this paper primarily revolves around the selection of suppliers in NPD collaboration, and thus, we will be primarily concerned with uncertainty regarding inputs, and will investigate this from the buying firm's perspective.

Uncertainty refers to situations where outcomes are not known, and in cases of genuine uncertainty, the means towards reaching outcomes (i.e. inferences) are not known either (e.g., Knight, 1921). Different categories of innovation uncertainties have been suggested (see e.g. Lane and Maxfield, 2005). Freeman (1982) suggests that uncertainty pertaining to innovations can be categorized into technical uncertainty, market uncertainty, and political/economic uncertainty. Elaborating on this framework, Hall and Martin develop a classification of innovation uncertainties (Hall et al., 2011; Hall and Martin, 2005). They propose four different types of uncertainties that produce obstacles in the process of turning an invention into an innovation: technological uncertainty, commercial uncertainty, organizational uncertainty, and social uncertainty. We argue that this classification can be used to assess uncertainties arising in NPD supplier selection processes, as it distinguishes between the relevant types of innovation uncertainties that may influence supplier selection somewhat differently. Social uncertainty involves the important diffusion phase of innovation, where social uncertainty revolves around the legitimacy of the societal impact of the innovation. As early stage NPD collaboration mainly concerns uncertainties regarding inputs, we will not analyse social uncertainty.

A cornerstone in Hall et al's (2011) framework consisting of technological, commercial, organizational and social (TCOS) uncertainties, is the paradigmatic nature of technological evolution that influences innovation uncertainties. Technological evolution has been described as advancement along specific technological trajectories and paradigms (Dosi, 
1982; Malerba and Orsenigo, 1996; Nelson and Winter, 1982). Trajectories usually comprise elements that are associated with a specific technology, but also include elements that are common to a broader range of technologies. Technological trajectories denote the way knowledge enfolds with regard to a specific technology, technological opportunities, the problem-solving strategies and heuristics that are developed and utilized, and the technological advancements that take place. Technological evolution may occur by means of continuous change or as a result of discontinuous paradigm shifts. The existence of several partially competing trajectories leads to uncertainty. As elaborated by Tushman and Anderson (1986) and Henderson and Clark (1990), some technologies will be among the trajectories already embarked upon by incumbent firms, while other technologies imply a paradigmatic shift, and technology managers therefore face difficult uncertainties involving both competence-enhancing and competence-destroying innovations.

Hall and Martin (2005: 279) and Hall et al. (2011: 1149) focus chiefly on the type of uncertainty that must be overcome in order for an idea or invention to become an innovation. They posit that with regard to i) technological uncertainty, the concept must be technologically feasible; ii) commercial uncertainty, it must be commercially viable; iii) organizational uncertainty, it should be congruent with corporate strategies, capabilities and organizational structures.

\section{Supplier selection and uncertainty}

In product development, firms rely upon specialized suppliers for components and subsystems. The specialization of such suppliers often concerns the specific technology they use for producing that specific component/sub-system. Hence, suppliers may be more or less tightly associated with development along a specific technological trajectory and selecting such a supplier may involve a commitment to a specific technology. In conducting technology selection, criteria and factors for consideration may also be understood differently among individuals involved in the selection process (Shehabuddeen et al., 2006). However, as a unit, buying firms need to be technically competent in order to properly assess suppliers' technology (von Corswant and Tunälv, 2002).

Market structure influences the selection process. For some technologies there are many competing suppliers, while in others, there are only a few, and some technologies or specific components may be proprietary to only one supplier. Whether or not the technology is critical for the product also affects the selection process. If the technology is critical to the product 
and the number of available suppliers is limited, then a detailed technological assessment of the potential supplier may take place (Handfield et al., 1999). Previous research has argued that supplying firms are diverse with respect to their capabilities, and that collaborative partnerships should be reserved for suppliers with outstanding technology and sophisticated management (Kamath and Liker, 1994). For instance, Bonaccorsi and Lipparini (1994) report on a case study where the buying firm surveyed the sites of potential suppliers, and then reviewed and analysed data to select a set of potential partners for NPD. This in turn led to shorter product cycle, better products, and improved competitiveness.

One aspect is the supplier's strategic focus on innovation as this is considered to have an impact on the supplier's product development activity (Wynstra et al., 2010). In addition, the supplier should be technically competent in order to integrate the technological frontier into the final product. However, for future NPD projects, the supplier's cooperativeness can be more important than its technical competence (McCutcheon et al., 1997). In uncertain situations, cooperative competencies may complement technological competencies (Tyler, 2001). Hence, it seems to be important for firms to be able to easily collaborate within the NPD project. One aspect of this is demonstrated by McIvor et al. (2006), who stress the importance of having a culture that facilitates and encourages collaboration between the firm and its supplier.

A firm that is searching for a supplier to include in an NPD project needs to consider several aspects of the potential suppliers. Alignment between the firm and the potential supplier can facilitate future collaboration. In the selection of a partner for collaboration, three forms of alignments are discussed: technological alignment, strategic alignment and relational alignment (Emden et al., 2006). Technical alignment refers to technical capability, resource complementarity and overlapping knowledge bases, while strategic alignment concerns motivation and goal correspondence. Finally, relational alignment includes compatible cultures, the propensity to adapt and long-term orientation. In addition to alignment, it is important to find a supplier that can develop the new product and implement new technologies. However, this does not only include specific technological competencies, but may also include the ability to provide an outside point of view for the firm (Wagner and Hoegl, 2006).

After a firm has completed the supplier selection, there may be uncertainty or doubt as to whether the supplier selected is the most suitable. Such uncertainties can reduce supplier involvement in NPD projects or even result in the firm changing suppliers (van Echtelt et al., 
2008). To change supplier once investments in co-design activities already have been made can be costly (Zirpoli and Caputo, 2002) and could also result in late market entry. It has been suggested that uncertainties concerning the selection of the most appropriate supplying firm could be handled by involving several suppliers in the NPD project (Langner and Seidel, 2009; Zsidisin and Smith, 2005). However, such a strategy may also be costly and dilute the focus of all parties involved.

Although the reviewed literature identifies a number of uncertainties regarding supplier selection, we argue that there is a lack of a unified framework for analysing the impact of both technology-related and supplier-specific factors in the selection processes and subsequent outcomes in terms of the commitment of the buyer to specific suppliers. Against this background, we conducted a single-case study of supplier selection in a collaborative NPD project.

\section{Research methodology}

The choice was made to conduct a qualitative case study, as we aimed to explore and systematize causal factors influencing supplier selection under uncertainty (George and Bennett, 2005). We selected the firm EnerTrans for further investigation as it is a large system integrator that is used to collaborating with suppliers in NPD. In sampling our case, we applied a purposive sampling strategy, which focuses on selecting a case that is particular instructive for the purpose of the research and understanding the general phenomenon (Flick, 2006; Patton, 2002; Siggelkow, 2007). The purpose of this research is to understand and explain the effects of uncertainty on both supplier selection and technology selection. In line with Siggelkow's (2007) discussion on selecting interesting cases, this involved selecting a case more unique than buyer-supplier collaborations in general, which usually involves only one of the two uncertainties. In this research, we drew upon a multiple case study of six different buyer-supplier collaborations in NPD, where one of the cases were particularly salient as it exhibited problems of both supplier selection and technology selection, while the others did not. The case selected was also rich on incidents where management had to deal with different types of uncertainties. The case clearly demonstrated the effects of uncertainty, where in fact the firm had to change supplier during the development project. To ensure that we could obtain rich information (Patton, 2002), the firm actively participated in the sampling. First, an initial meeting at the firm was arranged where NPD projects that would be suitable projects to study were discussed. Individuals involved in the firm's strategic 
decisions about product development, such as the senior vice president, the technology manager, the manager of marketing and sales and the manager of business development were present at this meeting. A handful of projects were discussed and the project perceived as most interesting for this study was selected in collaboration with the firm.

Before commencing interviews, we prepared an interview guide that incorporated the main topics for discussion with the respondents. The interview guide was developed to be flexible and allow for follow-up questions. The respondents were selected in close discussion with the managers involved in the project, to ensure that the respondents had insight into the project and could provide relevant information. Furthermore, all of the respondents had been involved, if not during the whole process, then at least in some of the part of the project that was studied. Interviews with individuals with different areas of responsibility, who belong to different departments and who have different roles and responsibilities in the project, were conducted (Eisenhardt and Graebner, 2007). This gave us the opportunity to gain different views of the project, uncertainties, processes, meetings and decisions that the firms have made. However, the main source of respondents was from the focal firm. It was, however, only possible to gain access to the project manager at one of the two suppliers. The interview data was collected through 11 semi-structed interviews which were mainly conducted face-toface (Kreiner and Mouritsen, 2005). These are presented in table 1, where information regarding respondent, duration of the interview and the respondent's role in the project are included.

\section{Table 1}

Respondent information organized in chronological order of interviews

\begin{tabular}{lcl}
\hline Respondents & Duration & Role in the project \\
\hline Project Manager & $1.5 \mathrm{~h}$ & The second project manager, 2008-2010 \\
Technical Manager & $1.5 \mathrm{~h}$ & Responsible for technical resources \\
Market Communicator & $2 \mathrm{~h}$ & Responsible for marketing material \\
Business Development Manager & $1.5 \mathrm{~h}$ & Idea generator and have followed the project continuously \\
Manager Marketing and Sales & $1 \mathrm{~h}$ & Responsible for sales \\
Senior Vice President & $1 \mathrm{~h}$ & Member in the project's steering committee \\
Supply Manager & $1.5 \mathrm{~h}$ & Partly responsible for the contact with the second supplier in \\
& $1 \mathrm{~h}$ & the project \\
R\&D Manager & $1 \mathrm{~h}$ & Responsible for development projects \\
Regional Sales Manager & $2 \mathrm{~h}$ & developed product \\
& $1 \mathrm{~h}$ & The first project manager, 1999-2008 \\
Project Manager & $14 \mathrm{~h}$ & \\
Project manager (supplier $\beta$ ) & & \\
Total & &
\end{tabular}

Extensive marketing material in the form of brochures, presentations and documents were studied. Additional secondary data about the project were the company's internal documents, 
such as the description of the stage-gate system used for developing projects. Technical information about the product was collected through articles about the technology, technical brochures, descriptions of the technologies and the supplier's home page and marketing material. Information about the development of energy storage systems included reports available from the United States Department of Energy. After completing the data collection, the data was presented and verified in a workshop at EnerTrans where ten individuals belonging to the R\&D department and the supply organisation participated. Our findings were discussed within the group, and details were clarified and additional data was gathered.

Triangulation was obtained by using multiple data sources; we studied documents, conducted interviews and performed a workshop. Our findings were presented in a workshop at EnerTrans, as this was a way to verify our results and discuss them with the firm. We used several tactics to ensure internal validity, and we studied significant literature and connected our results to existing literature. Furthermore, we created case study protocols and stored our data in a database to ensure reliability (Yin, 2009). In this study, time lines were created to facilitate the understanding of important milestones in the projects, allowing for awareness, assumptions and pre-understanding in the interpretation (Alvesson and Sköldberg, 2009). In this mapping, core situations, such as problematic events in the project, were identified and interpreted. Furthermore, a detailed case description was written in which the respondents' views of important episodes are presented. In accordance with Eisenhardt (1989a), a withincase analysis, which includes detailed case write-ups, was made. Sections 4 and 5 draw upon our case description. In this paper, we introduce several terms that are explained in table 2.

\section{Table 2}

Explanations of terms used in this paper

\begin{tabular}{ll}
\hline Formulation & Explanation \\
\hline EnerTrans & Fictitious name for our studied firm, the buying firm \\
Technology 1 & First battery technology $\left(\mathrm{Na}-\mathrm{NiCl}_{2}\right)$ selected \\
Supplier $\alpha$ & First supplier in the NPD project, contributed with technology 1 \\
Technology 2 & Second battery technology (Li-Ion) selected \\
Supplier $\beta$ & Second supplier in the NPD project, contributed with technology 2 \\
\hline
\end{tabular}

Further, we coded the data in order to identify the different forms of uncertainties that were present. This coding involved a number of steps in data reduction, data display and analysis (Miles and Huberman, 1984): both data-driven and theory-driven (Namey et al., 2007). The first step of data reduction was primarily inductive and a included the compilation of a list of variables that were grouped crudely into the two main categories of technological and strategic uncertainty, respectively. In a second step, these variables were categorized and 
displayed using the general framework of Hall et al (2011), which allowed for further consideration, refinement and specification of variables and what would constitute low vs. high values in each category of uncertainty. An important guiding principle in this analysis was the identification of generic problems involved in different types of uncertainties. The resulting matrix therefore displayed several fine-grained "polar" sub-categories of technological, organizational and commercial uncertainty as discussed in the Hall et al (2011) framework. Accordingly, the findings displayed in Tables 4-6 thus represent both general theory-driven - suggestions on the nature of different types of uncertainties, as well as casespecific and data-driven findings pertaining to these uncertainties as identified in this particular single-case study. In the final step, drawing upon the case findings conjectures were made on the relationship between the various sub-categories of uncertainty and selection outcomes. This step introduced further inferential reasoning to the proposed framework on uncertainty and effects on selection of technology and supplier, at the same time narrowing the scope of application to this specific setting of buyer-supplier collaboration in NPD.

\section{Energy storage: a case of technology and supplier selection}

In this section, we present the findings from our case study of an NPD project at a firm that we denote EnerTrans. This firm has over 100,000 employees and operates worldwide. EnerTrans aimed to create a new subsystem - an energy storage unit - for one of its main products: power transmission systems. Collaboration with external suppliers was sought, since the energy storage used battery technology, a technology new to EnerTrans.

The integration of energy storage into transmission and distribution systems has the potential to provide significant benefits to the grid and delivery of electricity. Figure 1 describes the development stages of the energy storage, from the battery cell component to the complete system. In this case, the supplier assumed responsibility for development of the battery cell and the battery module, while it was EnerTrans that developed the energy storage room, the surveillance and control system, and in the end, the complete power transmission system. For high-voltage and high-current applications such as stationary storage, a number of battery cells are packaged into a module, and a number of modules are packaged in a battery stack. 


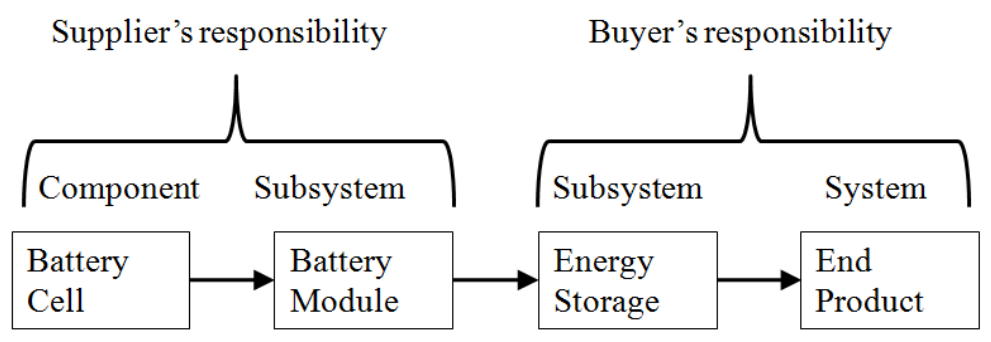

Fig. 1. NPD from component to complete system

There is considerable uncertainty surrounding future technological trajectories for energy storage, but this study focuses on the two different battery technologies that EnerTrans used in the NPD project. Previous to the development of the energy storage unit, the development of power transmission technologies (e.g., transformers, switchgear, protection devices) was unrelated to the development of battery technology. ${ }^{1}$ Two different battery technologies which could provide reliable rechargeable storage technology were used in this project: technology 1, which was a saltwater-based battery, and technology 2, which was a Li-Ion based battery. However, looming in the background was also the traditional battery technology, Ni-Cd, which had been used in large battery applications previously.

Technology 1 is a long-proven technology with performance characteristics that makes it suitable for electric vehicles and hybrid electric buses (Dustmann, 2004). These characteristics include the batteries being safe to handle, having a long life and being easy to recycle. This battery is based on $\mathrm{Na}-\mathrm{NiCl}_{2}$. Technology 2, the Li-Ion battery technology, has received a lot of attention lately. Many firms have commenced manufacturing this type of battery with governmental subsidies. Li-Ion cell chemistry offers another option for electrical energy storage for high-power and high-energy applications such as transportation and stationary storage, due to its electrochemical potential, theoretical capacity, and energy density (Daniel, 2008). The development of the NPD project is described in figure 2.

\footnotetext{
${ }^{1}$ More than a century ago, in the inception of the electrical power transmission industry, batteries were a component in direct current power transmission systems (in particularly in the UK). However, with the victory of alternating current technology in the "battle of the systems" at the turn of the $20^{\text {th }}$ century, the use of batteries rapidly faded away in power transmission systems (see Tell, 2007)
} 


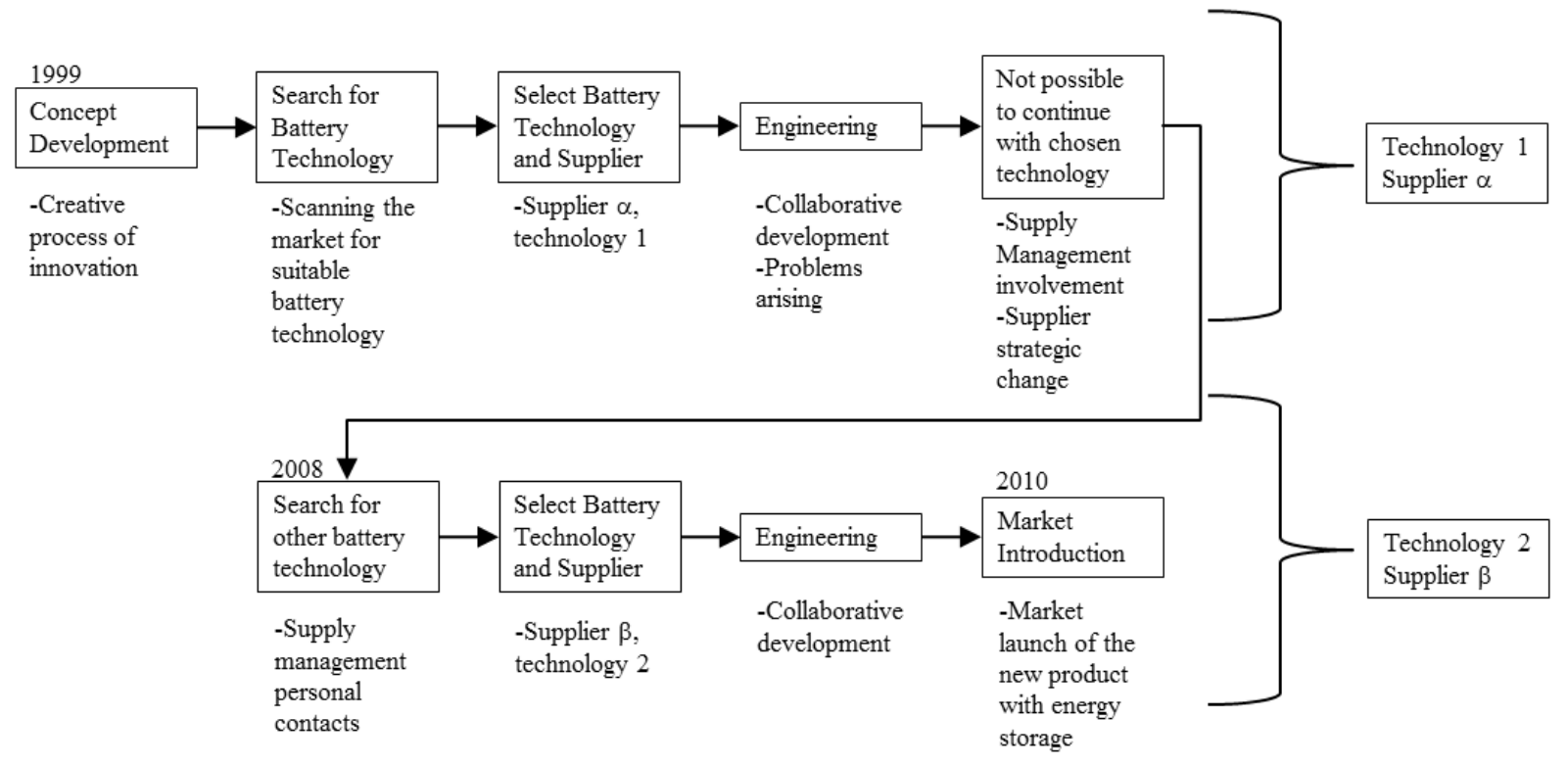

Fig. 2. The NPD project's process with supplier involvement

\section{Technology 1 and supplier $\alpha$}

The project started in 1999 when EnerTrans realized that the evolution of battery technology provided opportunities for the creation of energy storage for power transmission. EnerTrans did not plan to develop batteries themselves. Instead, the batteries were to be developed and manufactured by an expert supplier and then subsequently integrated into the energy storage system. Therefore, EnerTrans began a selection process in which two main technologies were assessed: technology 1 and technology 2. The assessment showed that technology 2 was not sufficiently mature at this stage to be used in the project, and was therefore excluded. Technology 1, on the other hand, was a fully developed battery and had been proved to function in other applications and was therefore selected. As technology 1 was proprietary to supplier $\alpha$, the selection of the technology resulted in a simultaneous selection of the supplier.

As the collaboration in the project progressed, it became clear that supplier $\alpha$ did not have enough resources or knowledge to develop a high voltage battery for EnerTrans. This was due to the history of supplier $\alpha$, which prior to the NPD project had been divided into two separate companies. In this split, the R\&D department of supplier $\alpha$ had been removed from the firm and thus, supplier $\alpha$ lacked fully developed R\&D resources. In addition, supplier $\alpha$ focused on manufacturing and possessed limited resources for the further development of technology 
1. Therefore, EnerTrans had to become more involved in the development of the battery than was originally planned.

"Supplier $\alpha$ did not have sufficient technological knowledge, we had to design the battery and help them" (Project Manager, EnerTrans)

Technology 1 did not constitute a problem in itself; it was supplier $\alpha$ that did not have the necessary knowledge, capabilities, processes, organisation and structure. This was demonstrated by how supplier $\alpha$ could not: a) meet business expectations, or; b) manage large complex NPD projects, either technically or organizationally. Additional problems arose: i) supplier $\alpha$ could not provide a warranty for the batteries ii) supplier $\alpha$ changed strategy from manufacturing large volumes of physical batteries to a licensing strategy i.e., to selling the rights to manufacture the technology 1 batteries. This had important implications for EnerTrans who did not have the intention to manufacture batteries. Even though the development of the energy storage unit had come quite a long way using technology 1 , EnerTrans decided to discontinue using technology 1 batteries despite the fact that it was a promising technology with manageable uncertainties. Hence, EnerTrans found itself in a situation where supplier $\alpha$ was the only manufacturer of technology 1 batteries, and therefore decided to find a new battery technology as well as a new supplier.

\section{Technology 2 and supplier $\beta$}

In 2008, EnerTrans returned to the initial evaluation of technologies, investigated the progress of technology 2 and believed it was now sufficiently developed to be a suitable technology. The selection of supplier $\beta$ was based on a number of factors. First, the supply manager had prior experience of supplier $\beta$ from a previous position outside EnerTrans. Second, supplier $\beta$ had been a part of the original evaluation of possible battery technologies when EnerTrans had investigated supplier $\beta$ 's battery development. Third, EnerTrans had past experience of supplier $\beta$ in another battery project. Finally, supplier $\beta$ was viewed as a technically skilled and competent supplier used to high quality demands, as it delivers batteries to both the space and military industry. There were also doubts as to whether technology 2 would prove to be the best solution, and therefore EnerTrans wanted to obtain some flexibility, allowing for changes in battery technology and design. 
"There is no ambition to learn a lot about technology 2, as there is a possibility that the technology for energy storage will change fast and another solution will be better" (R\&D Manager, EnerTrans)

There were uncertainties related to the high voltage application in energy storage, while technology 2 had not been tested using high voltages. Simulations had been made, but it remained to be seen how the battery would behave mechanically. In addition, there were uncertainties regarding magnetic fields and electrical architecture. Market uncertainty was also considered high, since there were few customers for this system at the high-end market who were willing to commit to such substantial investments. It was not only technological uncertainty that prevented EnerTrans from forming a close collaboration with supplier $\beta$. EnerTrans did not want to form close ties with supplier $\beta$ or share too much information. This was because EnerTrans was aware of the risk that supplier $\beta$ could gain technological and market knowledge and in the future become a competitor in the market for energy storage solutions for grid applications. The risk of spillovers and the leakage of important information was considered to potentially endanger EnerTrans' business.

\section{Comparison of technology and supplier}

Figure 3 shows EnerTrans' discretion in the supplier selection process, and how the supplier selections were affected by each technology. When selecting technology 1 , there was no supplier selection process because there was only one supplier for technology 1 . In contrast, by selecting technology 2 in the second search for technology, EnerTrans could choose among a number of available suppliers.

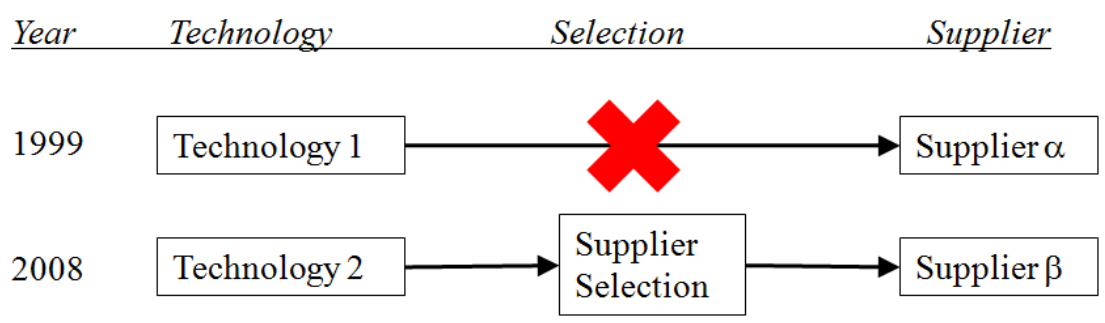

Fig. 3. Technology and supplier selection

There were several differences between battery suppliers $\alpha$ and $\beta$, some of which are listed in table 3. One obvious difference was the size, global presence, structure and organization of the companies, as supplier $\alpha$ was a small company with limited experience and organization whereas supplier $\beta$ was larger, had a global presence, experience in $R \& D$ 
collaboration and was also well known in the industry. The buyer-supplier interdependencies differed between the two suppliers, as supplier $\alpha$ was the only source of technology 1. For technology 2 there were several suppliers, and EnerTrans had the flexibility or being able to change supplier but keep the technology. For instance, the development efforts made by EnerTrans for technology 2 could be used in collaboration with a new supplier, whereas the lessons learned regarding technology 1 could not be reused.

Table 3

Supplier differences and implications for the project

\begin{tabular}{|c|c|c|}
\hline Characteristics & Supplier $\alpha$ & Supplier $\beta$ \\
\hline Size of company & $\begin{array}{l}\text { Small privately owned company with } \\
\text { limited experience of collaborating } \\
\text { with a large client }\end{array}$ & $\begin{array}{l}\text { Mid-sized, well known global company with a } \\
\text { history of working with many large firms }\end{array}$ \\
\hline $\begin{array}{l}\text { Buyer-supplier } \\
\text { dependence }\end{array}$ & $\begin{array}{l}\text { High dependence. Only one supplier } \\
\text { (supplier } \alpha \text { ) available }\end{array}$ & $\begin{array}{l}\text { Low dependence. Several suppliers available } \\
\text { on the market }\end{array}$ \\
\hline Volume & $\begin{array}{l}\text { Not possible to deliver required } \\
\text { volumes }\end{array}$ & Possible to deliver to expected demand \\
\hline Project objective & Not clarified & Structured and clear level of ambition \\
\hline
\end{tabular}

Some consequences that resulted from the project due to the change from technology 1 to technology 2 were an increased cost of batteries, increased cost due to the restart of the project, delay in market launch, and increased complexity of system-monitoring. Implications for the project resulting from the change from supplier $\alpha$ to supplier $\beta$ were an increase in perceived freedom for the buyer, a more structured organisation, and a change of power relation. Moreover, EnerTrans and supplier $\beta$ also managed to agree on a long-term strategic ambition without a formal contract.

\section{Seeking flexibility with supplier $\beta$}

EnerTrans' strategy was to remain flexible and had they no intentions of signing an exclusivity contract with supplier $\beta$. Nor did EnerTrans desire to enter a closer partnership involving future long-term collaboration with supplier $\beta$. Below we list the general reasons for EnerTrans not forming a close collaboration:

- Technological evolution: EnerTrans found it important to remain flexible and be open to the future creation of new energy storage solutions using technologies that could be superior to technology 2.

- Competition in the value chain: EnerTrans believed that supplier $\beta$ could decide to move downstream, enter the energy storage market and become a future competitor. 
- Spillovers/leakage: EnerTrans did not want to share information; this included both technical information about the energy storage and its integration, as well as commercial information, such as business case descriptions or knowledge of the industry. First, there was the risk of future competition from supplier $\beta$ alluded to above, and second, there was a perceived risk that supplier $\beta$ could leak information to current competitors to EnerTrans that also collaborated with supplier $\beta$.

- Cost competition: another supplier might be able to deliver technology 2 batteries at a better price than supplier $\beta$. Avoiding a single source situation could give EnerTrans an edge in negotiations.

Not having a contract was a way for EnerTrans to remain flexible. However, a change of supplier while maintaining technology 2 was estimated to require two years of development. Further, EnerTrans was not sure that the energy storage they had created would be the most suitable in the years to come; battery technology research was in a vibrant phase with global activity, and a new solution could arise in the near future. Such a solution could be either a new battery solution or a radical new technology.

"We have chosen not to have any close relation with supplier $\beta$ since there is a lot happening regarding energy storage and we want both companies to have the possibility to walk away" (Supply Manager, EnerTrans)

\section{Uncertainty, supplier selection and effects on selection outcomes}

Analysing innovation and supplier and technology selection in collaborative NPD, in line with Hall et al (2011), we differentiate between technological uncertainty, commercial uncertainty and organizational uncertainty.

\section{Technological uncertainty}

Table 4 outlines some key problems associated with technological uncertainty and shows how these affect uncertainty during the selection process and possible selection outcomes. Technological uncertainty involves both techno-paradigmatic problems, as well as problems related to technological complexity. Techno-paradigmatic problems refer to uncertainty pertaining to technological trajectories and paradigms (Dosi, 1982). In short, it is uncertain that any selected technology will still be the preferred technology in the future. Positive feedback reinforces continuous development along selected technological trajectories, but technological discontinuities also take place when competing technological paradigms 
substitute existing ones (Tushman and Anderson, 1986). While the former pattern of technological evolution implies some technological uncertainty, such uncertainty is manageable in the selection process. In contrast, in periods of technological discontinuities there is genuine uncertainty, as several options may be available, but the knowledge about the consequences pertaining to these options is limited, which makes managerial choice difficult.

Technological uncertainty was relatively high in this NPD project, as battery technology was evolving fast and EnerTrans aimed to be flexible in case new technologies emerged. In general, both rate of technological change and the level of the supplier's technological expertise influence technology selection (Brusoni et al., 2001; Handfield et al., 1999). When a technology is evolving fast, as is the case with battery technology, it is important to take technological uncertainty into considertation and identify emerging technological paradigms. Handfield et al. (1999) mention two problems in involving suppliers that pertain to technological uncertainty. The first problem lies in the fact that the firm may be locked into a specific supplier and its technology, and the second problem consists of a reduced incentive to innovate for suppliers; which slows down the pace of innovation. The first problem could be managed by conducting a thorough selection process. In this study, both the supplier and technology were selected concomitantly, in the first instance leading to a selection outcome that involved commitment to a (the only available) single supplier to collaborate with. Due to reasons other than the solely technological, this relationship was discontinued, and the second selection process aimed to find a solution that allowed for much more flexibility in future technological choices. This was also seen as a potential solution to mitigating the second disadvantage of high commitment to one supplier pointed out by Handfield et al (1999), since it made it possible for EnerTrans to keep the same technology, but change supplier if another supplier became a better option (i.e. in terms of innovation, reliability or cost).

By involving suppliers in NPD projects, buyers are likely to obtain better designs, especially in high-tech industries with complex products, since no single firm possesses expertise in potentially relevant technologies. This implies another dimension of how technological uncertainty affects supplier selection, namely through the complexity and interdependencies involved. In general, the complexity of systems refers to the number of elements and the interdependencies among those elements (Baldwin and Clark, 2000; Simon, 1962). Highly complex systems are those with many interdependent elements that are nondecomposable and these can be found in integral design architectures (Ulrich, 1995). Less complex systems have fewer elements and/or fewer interdependencies and are observable in 
modular design architectures (Baldwin and Clark, 2000). Obviously, there is a wide range of intermediate complex technological system, but for the sake of simplicity, we stick to these two archetypes.

The possibility to utilize specialization and tap into the knowledge held by competent suppliers is likely to lead to more informed decisions regarding technology and thereby better designs (Ragatz et al., 1997). EnerTrans made the concept development without any suppliers and searched for an appropriate technology themselves. In this way, the firm managed to be flexible and did not determine which technology to use at the beginning of the project, but instead, kept doors open for rival technologies. For EnerTrans, it was important to keep integration capabilities, although keeping these did not require expert battery knowledge since EnerTrans relied on the suppliers for battery knowledge. The battery unit was conceived of as a module with a predictable interface with the rest of the energy storage system. EnerTrans made the decision not to learn more than was required to be able to make good specifications for the supplier (Becker and Zirpoli, 2003; Schmickl and Kieser, 2008). The change of supplier and new collaboration was therefore not severely affected by the technological complexity of the system, and allowed for flexibility in selection outcomes over time. Rather than being an integral design of non-decomposable character, it seems as the design could be characterized as a nearly decomposable system (Simon, 1962), still complex, but allowing for the standardization of interfaces between modular sub-systems and the overall system.

\section{Table 4}

Technological uncertainties in the supplier selection process and impact on selection outcome

\begin{tabular}{lllll}
\hline Type of uncertainty & \multicolumn{4}{c}{ Technological uncertainty } \\
\hline Problem & \multicolumn{2}{c}{ Techno-paradigmatic } & \multicolumn{2}{c}{ Technological complexity } \\
Parameters affecting & Technological & Technological & Non-decomposable/ & Decomposable/ low \\
the selection process & continuity & discontinuity & high interdependence & interdependence \\
& Along trajectories & Paradigm shift & Non-predictable & $\begin{array}{l}\text { Predictable } \\
\text { interfaces }\end{array}$ \\
& & & interfaces \\
Selection outcome & Commitment & Flexibility & Commitment & Flexibility \\
\hline
\end{tabular}

\section{Organizational uncertainty}

Organizational uncertainty refers both to organizational fit and congruence in a specific NPD project. We suggest that such organizational fit (or lack thereof) may reside in intraorganizational (Hall and Martin, 2005) as well as inter-organizational (Emden et al., 2006; Lockström et al., 2010) problems (see table 5). Intra-organizational problems emanate from incongruences that arise when new technologies and new products are not aligned with the 
overall strategy, organizational structure, culture and capabilities of the buying firm. Interorganizational problems, on the other hand, are caused by inconsistent strategies, structures, cultures, capabilities, and the lack of managerial attention paid by the collaborating firms. In the case of both intra- and inter-organizational problems, an increase in incongruence leads to an enlarging gulf in the fit that signifies the prevailing uncertainty. As the degree of fit decreases, the buying firm starts looking for more options in the selection process, and is interested in remaining flexible in terms of selection outcomes.

With regard to intra-organizational fit this project was important to EnerTrans, as it demonstrated the firm's commitment to sustainable power solutions. The project's strategic importance was confirmed by the firm's top management that was very keen on presenting the project at the corporate level. Internally at EnerTrans, the project was presented on both the internal and the external websites. Moreover, EnerTrans showed that it believed that energy storage was the solution for the future, although the general economic downturn severely affected the industry and no commercial project has been commissioned.

Instead, uncertainty with regard to inter-organizational fit was a key factor in EnerTrans' decision to change supplier. EnerTrans and supplier $\alpha$, did not have a satisfactory alignment; the firms were not compatible in structure, business experience or technical knowledge. Supplier $\alpha$ could not measure up to EnerTrans' requirements, and this resulted in uncertainty as to whether or not the product could be developed by the supplier. In R\&D collaborations, firms need to pay attention to the relationship distance between the parties as this affects any potential knowledge transfer (Cummings and Teng, 2003). In this study, the interorganizational fit was problematic with supplier $\alpha$ but not with supplier $\beta$. Indeed, there was a good inter-organisational fit between EnerTrans and supplier $\beta$.

\section{Table 5}

Organizational uncertainties in supplier selection and impact on selection outcomes

\begin{tabular}{|c|c|c|c|c|}
\hline \multirow{2}{*}{$\begin{array}{l}\text { Type of } \\
\text { uncertainty } \\
\text { Problem } \\
\text { Parameters } \\
\text { affecting the } \\
\text { selection process }\end{array}$} & \multicolumn{4}{|c|}{ Organizational uncertainty } \\
\hline & \multicolumn{2}{|c|}{ Intra-organizational fit } & \multicolumn{2}{|c|}{ Inter-organizational fit } \\
\hline $\begin{array}{l}\text { Parameters } \\
\text { affecting the } \\
\text { selection process }\end{array}$ & $\begin{array}{l}\text { New technology } \\
\text { congruent with } \\
\text { overall strategies, } \\
\text { organizational } \\
\text { culture, } \\
\text { organizational } \\
\text { structure, } \\
\text { capabilities }\end{array}$ & $\begin{array}{l}\text { New technology } \\
\text { incongruent with } \\
\text { overall strategies, } \\
\text { organizational } \\
\text { culture, } \\
\text { organizational } \\
\text { structure, } \\
\text { capabilities }\end{array}$ & $\begin{array}{l}\text { Buying and supplying } \\
\text { firm congruent in } \\
\text { terms of strategies, } \\
\text { organizational } \\
\text { culture, } \\
\text { organizational } \\
\text { structure, capabilities, } \\
\text { management } \\
\text { attention }\end{array}$ & $\begin{array}{l}\text { Buying and supplying } \\
\text { firm incongruent in } \\
\text { terms of strategies, } \\
\text { organizational culture, } \\
\text { organizational } \\
\text { structure, capabilities, } \\
\text { management attention }\end{array}$ \\
\hline & $\begin{array}{l}\text { High intra- } \\
\text { organizational fit }\end{array}$ & $\begin{array}{l}\text { Low intra- } \\
\text { organizational fit }\end{array}$ & $\begin{array}{l}\text { High inter- } \\
\text { organizational fit }\end{array}$ & $\begin{array}{l}\text { Low inter- } \\
\text { organizational fit }\end{array}$ \\
\hline
\end{tabular}




\section{Commercial uncertainty}

Commercial uncertainty refers to a lack of knowledge about the commercial potential of a new technology (Hall et al., 2011) and if value from innovations created by the NPD collaboration can be captured by the buying firm. This implies that strategic problems pertaining to the collaborative venture have to be dealt with (table 6). One consideration is the appropriation of rents generated by the new technology (Teece, 1986). Such appropriation may depend on cost developments in manufacturing and opportunities for process innovations, but also on intellectual property protection. Other problems may arise out of conflicts of interests between the buyer and supplier as well as well as agency problems (Eisenhardt, 1989b; Rossetti and Choi, 2008).

EnerTrans was unsure about supplier $\beta$ 's strategy and was worried that it could become a future competitor. Cost development also constituted uncertainty. There were indications that the technology would become cheaper in the future, but this was contingent upon the future development of the automobile industry and the manufacture of electric cars. Another aspect that had to be considered was the risk of spillovers or leakage; both leakage to suppliers, who could use this knowledge to integrate vertically and become future competitors, but also through suppliers to current competitors.

EnerTrans made two technology selections that affected the form of collaboration. Using technology 1, which had only one supplier, meant that EnerTrans became dependent on supplier $\alpha$ to get access to the required technology. In the collaboration with supplier $\alpha$, the opportunities for EnerTrans to patent were limited. In the collaboration with the second supplier, EnerTrans was quite confident that technology 2 was a good choice for the future, but was not willing to make any long-term commitments to supplier $\beta$. By selecting technology 2, which had several suppliers, EnerTrans had the possibility to choose the form of collaboration more freely. Moreover, in this collaboration, EnerTrans had greater possibilities to file for patents, as the general technology used was not entirely proprietary. EnerTrans also believed that involving the supplier was hazardous, since this could lead to the risk that the supplier could acquire sufficient knowledge to become a competitor in EnerTrans' market segment. To avoid this, EnerTrans developed a collaborative form of limited supplier involvement and avoided sharing information. In addition, EnerTrans believed that cost of development constituted a major uncertainty and wanted to avoid a 
single source situation. EnerTrans wanted to avoid being locked into one specific technology or supplier and therefore chose to limit supplier involvement. 


\section{Table 6}

Commercial uncertainties in supplier selection and impact on supplier outcomes

\begin{tabular}{|c|c|c|c|c|c|c|c|c|}
\hline Type of & \multicolumn{8}{|c|}{ Commercial uncertainty } \\
\hline Problem & \multicolumn{2}{|c|}{ Buyer composition } & \multicolumn{2}{|c|}{$\begin{array}{c}\text { Supplier appropriation of } \\
\text { technology }\end{array}$} & \multicolumn{2}{|c|}{$\begin{array}{l}\text { Anticipated future vertical scope of } \\
\text { supplier }\end{array}$} & \multicolumn{2}{|c|}{ Cost development } \\
\hline \multirow{2}{*}{$\begin{array}{l}\text { Parameters } \\
\text { affecting the } \\
\text { selection } \\
\text { process }\end{array}$} & $\begin{array}{l}\text { Single } \\
\text { buyer/Monopsony } \\
\downarrow\end{array}$ & $\begin{array}{c}\text { Competing buyers } \\
\qquad\end{array}$ & $\begin{array}{c}\text { Proprietary } \\
\downarrow\end{array}$ & $\begin{array}{l}\text { Non- } \\
\text { proprietary } \\
\downarrow\end{array}$ & $\begin{array}{l}\text { Narrow } \\
\qquad\end{array}$ & Broad & $\begin{array}{c}\text { Predictable } \\
\downarrow\end{array}$ & $\begin{array}{c}\text { Non-predictable } \\
\downarrow\end{array}$ \\
\hline & $\begin{array}{l}\text { Currently no leakage to } \\
\text { direct competitors }\end{array}$ & $\begin{array}{l}\text { Potential risk of } \\
\text { leakage to } \\
\text { competitors }\end{array}$ & $\begin{array}{l}\text { Only single } \\
\text { source } \\
\text { available }\end{array}$ & $\begin{array}{l}\text { Multiple } \\
\text { sources } \\
\text { available }\end{array}$ & $\begin{array}{l}\text { Supplier } \\
\text { remaining } \\
\text { specialized } \\
\text { supplier }\end{array}$ & $\begin{array}{l}\text { Supplier } \\
\text { potential threat } \\
\text { by forward } \\
\text { integration }\end{array}$ & $\begin{array}{l}\text { Trend extra- } \\
\text { polation }\end{array}$ & $\begin{array}{l}\text { Multiple } \\
\text { scenario } \\
\text { forecasting }\end{array}$ \\
\hline $\begin{array}{l}\text { Selection } \\
\text { outcome }\end{array}$ & Commitment & Flexibility & Commitment & Flexibility & Commitment & Flexibility & Commitment & Flexibility \\
\hline
\end{tabular}




\section{Discussion and implications}

This study has highlighted the importance of supplier selection for NPD projects that involve selecting both a technology and a supplier. Drawing upon classifications developed by Hall and associates (Hall et al., 2011; Hall and Martin, 2005) we suggest that closer scrutiny of technological, organizational and commercial uncertainty may aid to further our understanding of supplier selection processes and outcomes in collaborative NPD projects. Our analysis of this particular case points to the fact that problems pertaining to technological, organizational and commercial uncertainty all support rigorous selection processes and flexible selection outcomes. While previous studies have indicated that uncertainty in buyersupplier collaborations calls for joint co-design process and commitment to the relationship (Spina et al., 2002), we argue that firms need a measure of flexibility in uncertain situations. Hence, there is a tension between supplier flexibility and supplier commitment arising out of uncertainty in collaborative NPD.

Our study demonstrates the need for more fine-grained analyses of uncertainty in relation to supplier selection, and we propose three main contributions. First, we discuss uncertainty as a precondition for the execution of collaborative NPD, and suggest that uncertainty can be categorized according to Hall et al. (2011) and Hall and Martin (2005), namely into technological, commercial and organizational uncertainty. We propose that technological uncertainty may require the firm to be flexible and not commit to one particular supplier or technology in order to be able to quickly change technology if another technology proves to be superior. Seconding these findings, Bhattacharya et al. (2013) show that firms use flexible and open-ended contracts as a way to manage technical uncertainty in outsourcing arrangements.

Second, we suggest that commercial uncertainty also imply a need for flexibility due to factors such as: appropriation, competition, leakage, and cost. Hence, despite current arguments on the importance of commitment to key suppliers, this study shows that rather than dedicating to sole suppliers, buyers seek flexibility, due to both technological uncertainty as well as commercial uncertainty. On the other hand, such flexibility-seeking behavior on behalf of the buyer also carries additional implications, as incentives for the supplier to collaborate may be reduced. However, as shown by Handfield et al. (1999) commitment to a supplier in a long-term relationship can also cause the supplier to lose incentive to innovate as the supplier may become comfortable in its position and does not need to compete with other 
suppliers. An important limitation of this research is therefore that only one of the two suppliers was investigated.

Third, and more in line with previous research, our study points to the importance of managing organizational uncertainty; including both intra-organizational and interorganizational fit. With regard to intra-organizational fit, we find that the individual project should contribute to the buyer's long-term objective (Wheelwright, 1992). Our study indicates that problems pertaining to inter-organizational fit were not considered at the beginning of the NPD project examined. The first supplier collaboration had to be aborted, which was due to non-compatibility of strategies between the buying firm and the supplier. Our findings confirm other studies that point to the importance of organizational fit (Hoegl and Wagner, 2005; Petersen et al., 2005) and capability fit (McCarthy et al., 2013) between the partners in NPD. In addition, the overall findings of this study regarding uncertainty contribute to research about alignment, where technological, organizational and commercial uncertainties in supplier selection are important considerations for technological, strategic and relational alignment (Emden et al., 2006).

More generally, our study indicates that technological, commercial and organizational uncertainty affect supplier selection for collaborative NPD. We identify mechanisms that explain why buying firms seek flexibility in technology selection and supplier selection, using a single case study (George and Bennett, 2005; Siggelkow, 2007). Future research could test the general applicability of these findings, by conducting studies of larger population of buyer-supplier collaboration in NPD. In particular, degrees of technological, commercial and organizational uncertainty need to be assessed, which calls for the development of uncertainty metrics. Moreover, the relative impact of various factors pertaining to each type of uncertainty needs to be assessed. This necessitates both further in depth single-case studies, which also involve supplier perspectives, as well as the use of comparative case studies or surveys. In this research, we have specified a set of uncertainty variables pertaining to technological, commercial and organizational uncertainties more broadly, based on observation of a single case in an industry characterized by high technological and system complexity. Future studies and analyses may assist in demarcating the boundary conditions of the framework suggested and to what extent findings can be extended also to other settings. Considering the amount of resources and time spent in industry on collaborative $R \& D$, we suggest that future research endeavors in this field should be rewarding indeed. 


\section{References}

Alvesson, M., Sköldberg, K., 2009. Reflexive methodology: New vistas for qualitative research. Sage Publications Ltd, London

Baldwin, C.Y., Clark, K.B., 2000. Design rules, Volume 1: The power of modularity. mIt Press, Boston

Becker, M., Zirpoli, F., 2003. Organizing new product development: knowledge hollowing-out and knowledge integration-the FIAT auto case. International Journal of Operations \& Production Management 23(9), 1033-1061.

Bhattacharya, A., Singh, P.J., Bhakoo, V., 2013. Revisiting the outsourcing debate: two sides of the same story. Production planning \& control 24(4-5), 399-422.

Bonaccorsi, A., Lipparini, A., 1994. Strategic partnerships in new product development: An Italian case study. Journal of Product Innovation Management 11(2), 134-145.

Brusoni, S., Prencipe, A., Pavitt, K., 2001. Knowledge specialization, organizational coupling, and the boundaries of the firm: Why do firms know more than they make? Administrative Science Quarterly 46(4), 597-621.

Clark, K.B., 1989. Project Scope and Project Performance: The Effect of Parts Strategy and Supplier Involvement on Product Development. Management Science 35(10), 1247-1263.

Cummings, J.L., Teng, B.S., 2003. Transferring R\&D knowledge: the key factors affecting knowledge transfer success. Journal of Engineering and Technology Management 20(1-2), 39-68.

Daniel, C., 2008. Materials and processing for lithium-ion batteries. JOM Journal of the Minerals, Metals and Materials Society 60(9), 43-48.

Dosi, G., 1982. Technological paradigms and technological trajectories: A suggested interpretation of the determinants and directions of technical change. Research Policy 11(3), 147-162.

Dustmann, C., 2004. Advances in ZEBRA batteries. Journal of Power Sources 127(1-2), 85-92.

Eisenhardt, Graebner, 2007. Theory building from cases: Opportunities and challenges. Academy of management journal 50(1), 25-32.

Eisenhardt, Tabrizi, 1995. Accelerating Adaptive Processes: Product Innovation in the Global Computer Industry. Administrative Science Quarterly 40(1), 84-110.

Eisenhardt, K., 1989a. Building theories from case study research. Academy of management review 14(4), 532550.

Eisenhardt, K.M., 1989b. Agency theory: An assessment and review. Academy of management review 14(1), 57-74.

Emden, Z., Calantone, R.J., Droge, C., 2006. Collaborating for new product development: selecting the partner with maximum potential to create value. Journal of Product Innovation Management 23(4), 330-341.

Fagerberg, J., 2004. Innovation: a guide to the literature, In: Fagerberg, J., Mowery, D., and Nelson, R (Ed.), The Oxford Handbook of Innovation. Oxford University Press, Oxford.

Flick, U., 2006. An introduction to qualitative research. Sage Publications Ltd, London

Freeman, C., 1982. The economics of industrial innovation, 2nd ed. Frances Pinter, London

George, A.L., Bennett, A., 2005. Case studies and theory development in the social sciences. Mit Press, Cambridge 
Grant, R.M., Baden Fuller, C., 2004. A knowledge accessing theory of strategic alliances. Journal of Management Studies 41(1), 61-84.

Hall, J., Matos, S., Silvestre, B., Martin, M., 2011. Managing technological and social uncertainties of innovation: The evolution of Brazilian energy and agriculture. Technological Forecasting and Social Change 78(7), 1147-1157.

Hall, J.K., Martin, M.J.C., 2005. Disruptive technologies, stakeholders and the innovation value added chain: a framework for evaluating radical technology development. R\&D Management 35(3), 273-284.

Handfield, R., Ragatz, G., Peterson, K., Monczka, R., 1999. Involving Suppliers in New Product Development? California Management Review 42(1), 59-82.

Henderson, R.M., Clark, K.B., 1990. Architectural innovation: The reconfiguration of existing product technologies and the failure of established firms. Administrative Science Quarterly 35(1), 9-30.

Hoegl, M., Wagner, S.M., 2005. Buyer-supplier collaboration in product development projects. Journal of Management 31(4), 530.

Johansson, M., Axelson, M., Enberg, C., Tell, F., 2011. Knowledge integration in inter-firm R\&D relationships: How do firms balance problems of coordination with problems of cooperation?, In: Bergek, A., M.

Hobday, C. Berggren, L. Bengtsson \& J. Söderlund (Ed.), Knowledge integration and innovation: Critical challenges facing international technology-based firms. Oxford University Press, Oxford.

Kamath, R.R., Liker, J.K., 1994. A Second Look at Japanese Product Development. Harvard Business Review 72(6), 154-170.

Knight, F.H., 1921. Risk, uncertainty and profit. Houghton Mifflin, Boston

Kreiner, K., Mouritsen, J., 2005. The analytical interview, In: Tengblad, S.a.C. (Ed.), The Art of Science. Liber/CBS Press, Copenhaguen, 153-176.

Lane, D.A., Maxfield, R.R., 2005. Ontological uncertainty and innovation. Journal of evolutionary economics 15(1), 3-50.

Langner, B., Seidel, V.P., 2009. Collaborative concept development using supplier competitions: Insights from the automotive industry. Journal of Engineering and Technology Management 26(1-2), 1-14.

Lockström, M., Schadel, J., Harrison, N., Moser, R., Malhotra, M.K., 2010. Antecedents to supplier integration in the automotive industry: A multiple-case study of foreign subsidiaries in China. Journal of Operations Management 28(3), 240-256.

Malerba, F., Orsenigo, L., 1996. The dynamics and evolution of industries. Industrial and Corporate Change 5(1), 51-87.

McCarthy, I.P., Silvestre, B.S., Kietzmann, J.H., 2013. Understanding outsourcing contexts through information asymmetry and capability fit. Production planning \& control 24(4-5), 277-283.

McCutcheon, D.M., Grant, R.A., Hartley, J., 1997. Determinants of new product designers' satisfaction with suppliers' contributions. Journal of Engineering and Technology Management 14(3-4), 273-290.

McIvor, R., Humphreys, P., Cadden, T., 2006. Supplier involvement in product development in the electronics industry: a case study. Journal of Engineering and Technology Management 23(4), 374-397.

Miles, M., Huberman, A., 1984. Qualitative data analysis: A sourcebook of new methods. Sage Publ.inc, Beverly Hills, CA 
Namey, E., Guest, G., Thairu, L., Johnson, L., 2007. Data reduction techniques for large qualitative data sets, In: Guest, G., MacQueen, K.M. (Eds.), Handbook for team-based qualitative research. Altamira Press, Lanham, MD, pp. 137-162.

Nelson, R., Winter, S., 1982. An evolutionary theory of economic change. Belknap Press, Cambridge Patton, M.Q., 2002. Qualitative research and evaluation methods, 3rd ed. Thousand Oaks, CA: Sage Publications., California

Petersen, K., Handfield, R., Ragatz, G., 2003. A model of supplier integration into new product development. Journal of Product Innovation Management 20(4), 284-299.

Petersen, K., Handfield, R., Ragatz, G., 2005. Supplier integration into new product development: coordinating product, process and supply chain design. Journal of Operations Management 23(3-4), 371-388.

Ragatz, G., Handfield, R., Petersen, K., 2002. Benefits associated with supplier integration into new product development under conditions of technology uncertainty. Journal of Business Research 55(5), 389-400.

Ragatz, G., Handfield, R., Scannell, T., 1997. Success factors for integrating suppliers into new product development. Journal of Product Innovation Management 14(3), 190-202.

Rossetti, C.L., Choi, T.Y., 2008. Supply management under high goal incongruence: An empirical examination of disintermediation in the aerospace supply chain. Decision Sciences 39(3), 507-540.

Schmickl, C., Kieser, A., 2008. How much do specialists have to learn from each other when they jointly develop radical product innovations? Research Policy 37(3), 473-491.

Shehabuddeen, N., Probert, D., Phaal, R., 2006. From theory to practice: challenges in operationalising a technology selection framework. Technovation 26(3), 324-335.

Siggelkow, N., 2007. Persuasion with case studies. The Academy of Management Journal 50(1), 20-24.

Simon, H.A., 1962. The architecture of complexity. Proceedings of the american philosophical society 106(6), 467-482.

Song, M., Di Benedetto, C., 2008. Supplier's involvement and success of radical new product development in new ventures. Journal of Operations Management 26(1), 1-22.

Spina, G., Verganti, R., Zotteri, G., 2002. A model of co-design relationships: definitions and contingencies. International Journal of Technology Management 23(4), 304-321.

Teece, D.J., 1986. Profiting from technological innovation: Implications for integration, collaboration, licensing and public policy. Research Policy 15(6), 285-305.

Tell, F., 2007. The electrical industry, In: Rider, C. (Ed.), Encyclopedia of the Age of the Industrial Revolution: A Global History. Greenwood Publishing, Westport, CT, 133-139.

Tushman, M., Anderson, P., 1986. Technological discontinuities and organizational environments. Administrative Science Quarterly 31(3), 439-465.

Tyler, B.B., 2001. The complementarity of cooperative and technological competencies: a resource-based perspective. Journal of Engineering and Technology Management 18(1), 1-27.

Ulrich, K., 1995. The role of product architecture in the manufacturing firm. Research Policy 24(3), 419-440.

Wagner, S.M., Hoegl, M., 2006. Involving suppliers in product development: Insights from R\&D directors and project managers. Industrial Marketing Management 35(8), 936-943.

Walter, A., 2003. Relationship-specific factors influencing supplier involvement in customer new product development. Journal of Business Research 56(9), 721-733. 
van Echtelt, F., Wynstra, F., van Weele, A.J., Duysters, G., 2008. Managing Supplier Involvement in New Product Development: A Multiple-Case Study. Journal of Product Innovation Management 25(2), 180201.

Wheelwright, S.C., 1992. Revolutionizing product development: quantum leaps in speed, efficiency, and quality. Free Press, New York

von Corswant, F., Tunälv, C., 2002. Coordinating customers and proactive suppliers: A case study of supplier collaboration in product development. Journal of Engineering and Technology Management 19(3-4), 249-261.

Wynstra, F., Von Corswant, F., Wetzels, M., 2010. In Chains? An Empirical Study of Antecedents of Supplier Product Development Activity in the Automotive Industry*. Journal of Product Innovation Management 27(5), 625-639.

Yin, R.K., 2009. Case study research: design and methods, 4th ed. Sage Publications, Los Angeles, Calif.

Zirpoli, F., Caputo, M., 2002. The nature of buyer-supplier relationships in co-design activities: the Italian auto industry case. International Journal of Operations \& Production Management 22(12), 1389-1410.

Zsidisin, G.A., Smith, M.E., 2005. Managing supply risk with early supplier involvement: a case study and research propositions. Journal of Supply Chain Management 41(4), 44-57. 